\title{
Factors Affecting Technology Transfer and Commercialization of University Research in India: a Cross-sectional Study
}

\author{
Ramya Ravi ${ }^{1} \cdot$ Manthan D. Janodia ${ }^{2}$ (D)
}

Received: 21 February 2020 / Accepted: 19 January 2021 / Published online: 24 February 2021

(c) The Author(s) 2021

\begin{abstract}
In recent years, there is a great emphasis on transferring inventions and technologies originating from academia to industry through technology transfer/licensing or commercialization. The efforts of the Government of India (GOI) aim to create socially useful innovation through university-industry technology transfer. The objective of the study is to examine and understand enabling factors and barriers for technology transfer among Indian universities. The study covers three key aspects: (1) the awareness and practice of patents and research commercialization among Indian academia, (2) comprehending strategies adapted to commercialize research activities, and (3) barriers in university-industry technology transfer (TT). This paper is an attempt to answer the research question whether current dynamics within Indian universities create an environment for enabling knowledge transfer/ commercialization and propose plausible suggestions to enable academia-industry technology transfer. A self- assessed structured methodology is contemplated and applied. Convenience sampling methods were adopted. Administrators of 25 universities overseeing research and development activities/patent cell/incubation cell or industrial collaboration of universities were approached to participate in the study. Indian universities are categorized as (i) public funded universities and (ii) private institutes for the purpose of the study. It is interesting to understand that public funded universities have an advantage in terms of receiving funds and licensing the research to potential industrial partners. The authors further conclude that research undertaken in academia is far from the demands of the industry. Even though the relevant supporting system for enhancing university-industry collaboration is in place, such as establishing technology transfer office (TTO) in the university, they hardly channelize the resources for socially useful innovation. It is important for Indian academia to undertake commercially viable research for the benefit of society.
\end{abstract}

Keywords Technology transfer · Commercialization · Industry-academia partnership $\cdot$ MHRD

Extended author information available on the last page of the article 


\section{Introduction}

Innovation is the direct outcome of structured and planned scheme of work, referred to as research. The competition among the industry is exceedingly independent of the research undertaken by public funded or private research organizations and universities. The main advantage of universities are the faculty members and students who constantly enter the system, bringing fresh concepts, ideas that eventually leads to research and innovation. Accessibility to results obtained from research is the core challenge to rebuild the ideas to innovation and further convert to commercially viable product (European commission, 2009). Thus, dissemination of innovation from universities and research institutions to parties capable of commercialization is defined as technology transfer (TT). The main objectives of technology commercializing include leveraging $R \& D$ outcome and intellectual assets, raise the accessibility of scientific outcome to broad range of consumers, development of new services and products ready for commercialization, and last but not the least, to intensify industrial competition. The transfer can originate either due to technology push (through research) or market pull (through industry). The international scope of technology commercialization may encompass developed nations, developing nations and other countries with economy transition (Thompson, 2015). In the current trend, universities must position themselves as authentic players to raise the chance of success in $R \& D$ probably by two aspects: increase in knowledge transfer by using scientific knowledge and raise the business value of knowledge transfer by introducing cutting edge breakthrough technologies (Baron, 2020). Though there is enough literature discussing cases of technology transfer from research institutions in developed nations, there are very few instances of knowledge transfer between universities and industries in India. Very few articles discuss technology transfer in Indian academia. Hyndman et al. studied and compared knowledge commercialization practices of Massachusetts Institute of Technology (MIT) with Indian academia. The author emphasized the lack of policy to support commercializing technology in India (Hyndman et al., 2005). Comprehending knowledge transfer models, practiced in the USA and Germany, Rath et al. proposed a model suited to Indian scenario that supports fiscal incentives to encourage largescale industry-academia partnerships. Further, the proposed model emphasized on channelizing the profit, obtained from commercialization of technology originating from university, to R\&D (Rath et al., 2014). A study by Srivastava et al. stressed upon the importance of creation of companies around academic technologies and job creation to promote the economic growth. Further, the study suggests that one commercialization model may not be successful in all universities, as there are differences in culture, resources, environment, and priorities among universities (Srivastava \& Chandra, 2012). A review by Pagar et al. explained the significance of continuous exchange of information between industry and academia to maintain the quality of the product transferred (Pagar et al., 2014). In the past decade there has been an emphasis on Indian academia to generate revenue from research outcomes, and hence, knowledge transfer/technology transfer becomes an integral part of discussion about Indian academia. 
As the availability of literature on the commercialization of technology in Indian academia is limited, this paper explores the state of knowledge exchange by presenting data on Indian universities regarding intellectual property and technology transfer practices in both public and private universities. The NIRF data for the year 2018 has also been used for the purpose of this study. The study covers three key aspects: (1) the awareness and practice of patents and research commercialization among Indian academia, (2) comprehending strategies adapted to commercialize research activities, and (3) barriers in university-industry technology transfer. The paper is an attempt to answer the research question whether the current dynamics within Indian universities create an environment for enabling knowledge transfer/ commercialization and proposes plausible suggestions to enable academiaindustry technology transfer. The study further aims to comprehend the scenario and recommend strategies to support technology transfer in Indian academia. The method used for the study proposes and implies a self-assessment concerning the activities of innovation and research commercialization capacity. Relevant results obtained from the respondents were cross verified with the publically available data for a few universities through their organization webpage. This allows a qualitative and semi- quantitative approach to the study.

\section{Literature Review}

\section{Evolution of Technology Innovation In India}

The past five decades looks progressive in terms of technology evolution in India, including innovation and research. The first scientific policy, enacted in 1958, emphasized on importance of technology in India. India has a history of success stories among a few research and development organizations. One such initiative is from National Chemical Laboratory (NCL innovations) - a chief laboratory of The Council of Scientific and Industrial Research (CSIR) under the central government of India. In its 80 years of existence, NCL has an impressive history of commercializing technology both within India and abroad in collaboration with industry. In 1950s, NCL was successful in launching organic chemicals and manufacturers of dye for the first time. In Green Revolution during 1960s, NCL played a significant role in establishing various agro- chemical based companies. In 1970s after the launch of Patent Act in India, NCL has worked with various pharma companies and developed manufacturing processes for drugs (Nandagopal et al., 2011). In 1988, the Technology Information Forecasting and Assessment Council (TIFAC), an autonomous body owned by Government of India under Department of Science and Technology, was established to provide financial support for infrastructure and to develop and commercialize technologies under "Home Grown Technology" Scheme (Kumar \& Jain, 2002).

Emphasizing the importance of promoting local goods, "Make in India" initiative launched in 2014 by Government of India includes the salient features to facilitate inventions, protect Intellectual Property, foster innovation, and build best manufacturing infrastructure in the country. In May 2016, first national IPR policy 
was released. Through this policy, GOI aimed to promote, create awareness, and enforce intellectual property. Moreover, the government prioritized to bring the administration of IP laws under Department of Industrial Promotion and Policy (DIPP) (Joseph, 2016).

The objectives of the policy were as follows:

- Emphasize the significance of intellectual property among all sectors in the society

- Stimulate creation of intellectual property by undertaking appropriate measures

- Have stringent IP laws, consistent with international obligations

- Modernize and strength IP administration and catalyze the commercialization of IP rights

- Strengthen the enforcement on combating IP violations

- Capacity development by strengthening and expanding human resources, institutions for training, research and skill building in IP (Joseph, 2016)

Adding to the initiatives promoting IP, "Cell for IPR Promotion and Management" (CIPAM) under the aegis of DIPP for promotion, creation and commercialization of IP assets were constituted. CIPAM enforced a nationwide promotion scheme titled "Creative India; Innovative India" to create awareness on the benefits of the new IPR policy. The duration for the scheme was for 3 years (April 2017 to March 2020). The primary objective of the scheme was to conduct IP awareness workshops/seminars in collaboration with industry organizations, academic institutions, and other stakeholders across the country (Department of Industrial Policy and Promotion, Ministry of Commerce and Industry and Government of India, 2016).

\section{Positioning of Indian Universities in Terms of IP Generation and Technology Commercialization}

The inception of formal technical education in India dates back to the mid-nineteenth century. In 1945, an All India Council for Technical Education (AICTE) was set at a national advisory body to facilitate the infrastructure for technical education in India.

Universities in India are governed by Department of Higher Education under the Ministry of Human Resources Development (now Ministry of Education), Government of India. Indian universities are categorized as public funded and private (state private or deemed to be) universities based on the University Grants Commission (UGC) Act 1956. Later in 1987, All India Council for Technical Education Act was constituted to regulate and sustain the standards in technical education system in India. In the past decade, there have been several amendments in legislative framework for the public universities under various states governance in India.

In 2008, The Protection and Utilization of Public Funded Intellectual Property Bill (PUPFIP) was proposed to address the challenges in the university-industry technology transfer. The provisions of the Bill were to provide incentives to the universities through public funded research wherein: 
- Ownership of patents remains with the academic institute on inventions from government funded projects.

- Institute creating an invention must inform the funding agency within 60 days of the creation.

- Research institute must inform the government agency about the intention to patent the invention within 90 days; if they fail to inform, under defined prior Acts, the agency will acquire the title of patent.

- Bill had the provision of $30 \%$ of royalties given to the inventor.

- On receiving the government aided funds, the research institute must frame an intellectual management committee to process the innovation in terms of assignment of rights, potential for marketing the invention in concern, licensing agreements.

There were a few concerns expressed with implementation of PUPFIP. The major mission of the bill was to commercialize the invention, which lead to fear of ignoring public concerns and priorities. Other major concern of the bill was nondisclosure requirement insisted by the government on the research institutes, thus increasing bureaucracy and suppressing innovations and academic exchanges. The Ministry of Science and Technology had created a board of authorities to support the entrepreneur generation and support through National Science and Technology Entrepreneurship Development Board (NSTEDB) in 2009. The NSTEDB had supported the creation of Technology Business Incubators (TBI) and Technology Parks. TBIs were created at IIT-Delhi, Chennai, Mumbai, Kanpur, Delhi University and Banaras Hindu University (BHU), Varanasi. Despite the initiatives, the research commercializing at Indian Universities are sub-par compared with developed nations (Srivastava \& Chandra, 2012).

In 2018, AICTE had initiated a program to empower faculty members by organizing a cell in all technical institutions, universities, deemed to be universities, and other institutions for training, known as AICTE Training and Learning (ATAL) academy. The main objective of ATAL academy is to impart quality technical education in India, support institutions in fostering research, innovation, and entrepreneurship through training. The training sessions are conducted through online portal in the form of workshops, orientations, learning communities, or faculty development programs. Government of India has announced to establish more than eleven such academies throughout the country (AICTE Training And Learning ( ATAL) Academy \& Govt. of India, 2020). Ministry of Human Resource Development (MHRD), Government of India, established MHRD's Innovation Cell (MIC) in 2019 to systematically foster the culture of innovation among all Higher Education Institutions (HEIs) in the country. The primary focus of MIC is to encourage, inspire, and nurture young students by exposing them to new ideas. Major programs under MIC include the following:

- Smart India Hackathon (SIH) 2019, a nationwide initiative, to inculcate a culture of product innovation and a mindset of problem solving (AICTE-India, 2019)

- Institution Innovation Councils (IIC) to create local innovation ecosystem and support scouting ideas and pre-incubation of ideas 
- Atal Ranking of Institutions on Innovation Achievements (ARIIA) is an initiative in India to rank all major higher educational institutions and universities in India on indicators related to "Innovation and Entrepreneurship Development" amongst students and faculty members. ARIIA is set to channelize the institutions towards becoming competent in global platform and be forefront in innovations. The major indications for consideration of the HEIs to be ranked under ARIIA are as follows: Budget and Funding Support, Infrastructure and Facilities, Awareness, Promotions and support for Idea Generation and Innovation, Promotion and Support for Entrepreneurship Development, Innovative Learning Methods and Courses, Intellectual Property Generation, Technology Transfer and Commercialization, and Innovation in Governance of the Institution.(MHRD's innovation council \& Govt. of India. (2019).

- National Innovation and Start-up Policy for Students and Faculty provides the framework on intellectual property ownership, revenue sharing mechanisms and norms for technology transfer, and commercialization (MHRD's innovation council, Ministry of Human Resource Development \& AICTE, 2019).

Earlier in India, the focus was on research and development, whereas now emphasis is also on creation of intellectual property and technology commercialization. Several universities have created facilities, infrastructure, and human resources to foster innovation, generate intellectual property, and commercialize academic research. This paper is an attempt to understand the barriers in commercializing academic research in India.

\section{Research Methodology}

The two main parameters underlying the study framework of research technology commercialization of the Indian universities includes the following:

- Details on patent activities carried out in the universities in the past 5 years (2013-2018)

- Revenue generated during the past 5 years (2013-2018)

The study framework for this research include qualitative and semi-quantitative analysis. The variables addressed in the study are represented in Table 1. Convenient sampling was adopted.

- Type of study: Cross-sectional study

- Duration of study: 2 years (June 2018 to June 2020)

- Sampling method: Convenience sampling

- Sampling unit: Administrators of universities responsible for research/intellectual property/ technology commercialization/incubation cell

- Sample size: 40 universities/institutes

- Type of questionnaire: structured questionnaire

- Data collection: in person where feasible, or through Google Form.

- Data analysis 


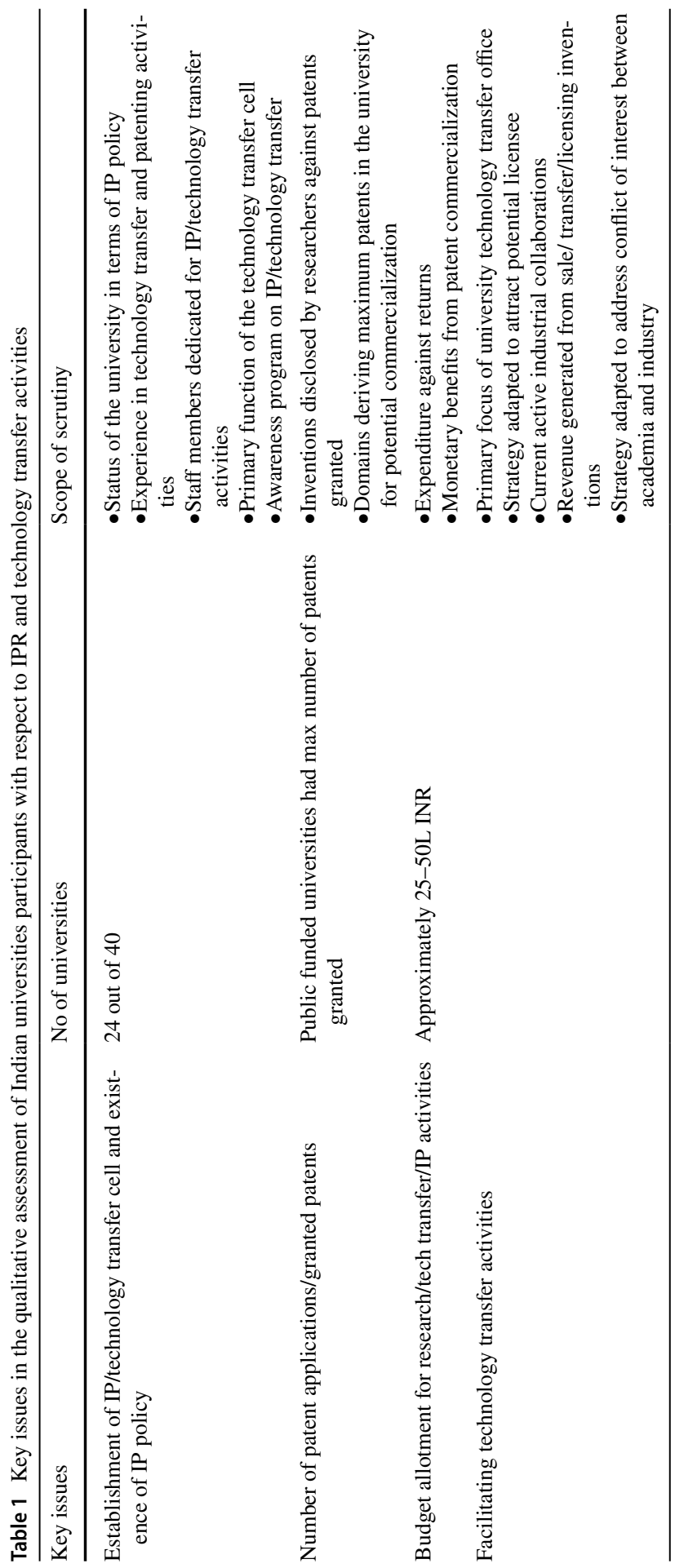


The questionnaire was designed by adapting the concept proposed by Association of University Technology Managers (AUTM) and Brazilian Survey of Technology transfer (Livesey, 2014). The questions in the questionnaire include descriptive, multiple choice, dichotomous, and scaled responses.

\section{Results and Discussion}

A total of 40 universities were approached for study of which only 25 responded with a response rate of $62.5 \%$. Among other 25 universities/institutes (one respondent did not have technology transfer/IP office and hence excluded from analysis), four organizations were central government institutions, seven organizations were state private universities/institutions, five organizations were deemed to be universities, while eight others were private research organizations. IP policy was implemented in 17 universities, whereas six of them mentioned that the policy was under preparation and would be implemented within 6 months. The responses help to understand that IP policy has become an integral part of the research system in Indian universities.

As shown in Fig. 1, $41 \%$ respondents had 2-5 years of experience in IP/TT, whereas $17 \%$ have more than 10 years of experience and $21 \%$ had less than a year or more than 6-10 years of experience.

The university/institute practiced customized strategies to transfer technology as shown in Fig. 2. As there was no specific model practiced for TT, personal contacts in industry were the most preferred approach to license the invention, whereas the other approach was to organize innovation exhibitions. All the organizations adapted a combination of strategies as needed.

Invention disclosure could be one of the important metric to assess innovation potential. In our study, it was observed that $33 \%$ of the universities had less than ten invention disclosures, whereas, $29 \%$ had more than 30 invention disclosures by the researchers in the past 5 years. Public universities correspond to higher number of invention disclosure due to higher quantum of funding received from the

Fig. 1 Number of years of experience in IP/TT

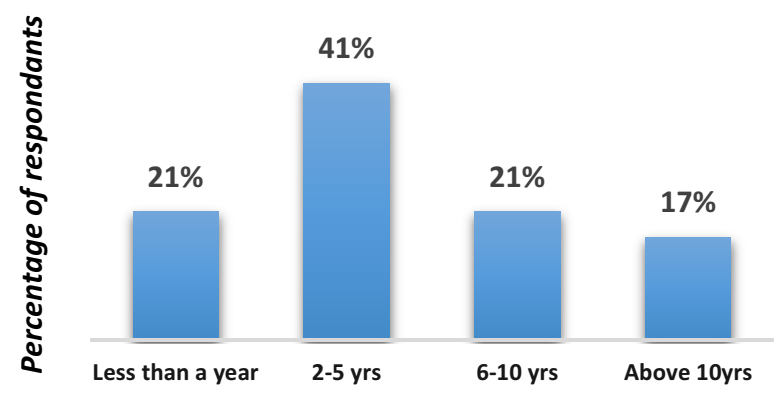

Number of years of experience in IP/TT 
Fig. 2 Strategies adapted by universities to attract potential licensee

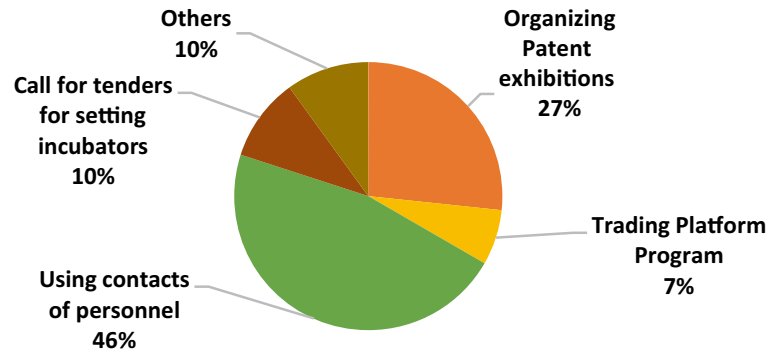

government. About $71 \%$ of the universities had entrepreneurship policy applicable to foster entrepreneurship among faculty members.

The number of patents granted to universities in past 5 years is shown in Fig. 3. As is visible, the number of patents granted to the universities improved from 2016 to 2017. The data obtained through questionnaire was cross-verified for a few universities with the details publically available on their website. On analyzing the results, the universities governed under state or central government are consistently performing well in terms of patent applications filed and number of patents granted.

We tried to understand the scientific fields that are considered having maximum potential for technology commercialization. Though many universities have expertise in various fields, medical sciences and biotechnology domains are considered having maximum potential for technology commercialization as shown in Fig. 4

The budget allocation of the universities for IP/TT activities in the past 5 years is shown in Fig. 5. The respondents stated that there was no separate budget allocated

a

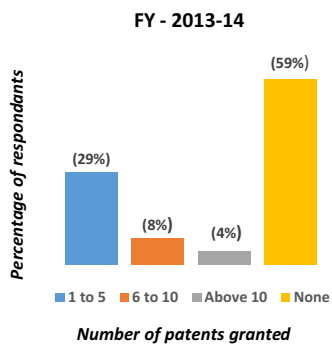

d b

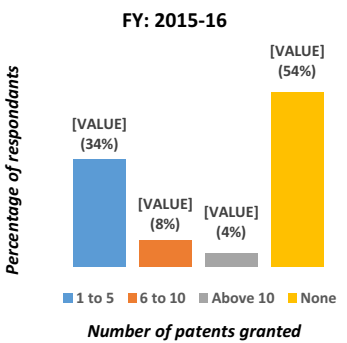

e c

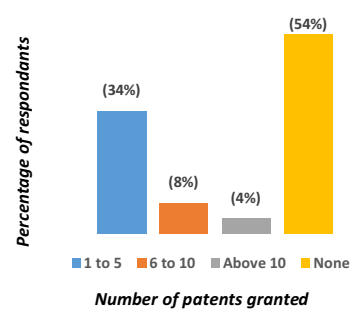

FY: 2017-18
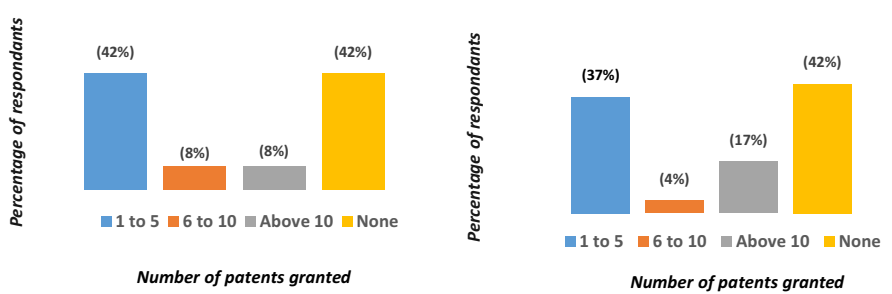

Fig. 3 Number of patents granted to universities in the past 5 years 


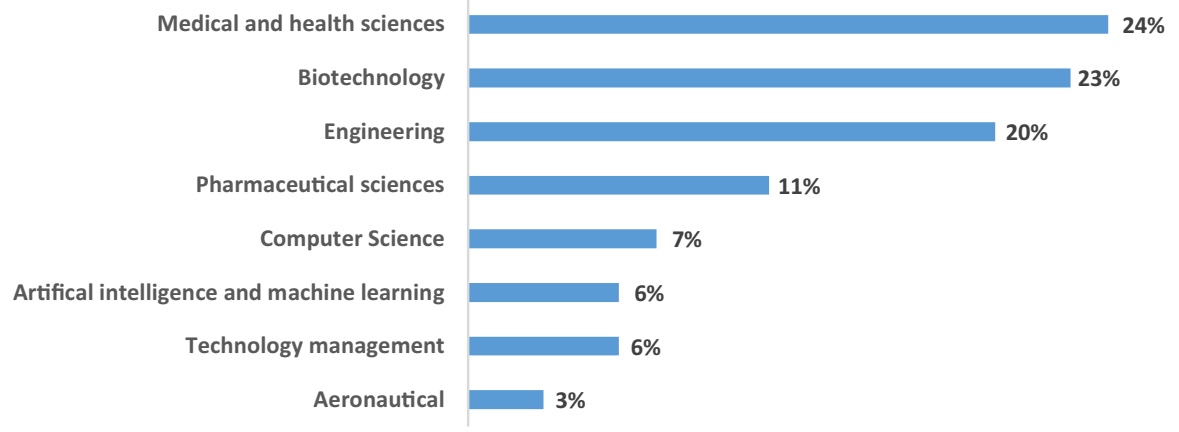

Percentage of respondants

Fig. 4 Domains deriving maximum inventions potential for commercialization

for IP/TT activities, but was included under research budget. The budget allocated in the last 5 years remains mostly unchanged.

We also tried to correlate budget allocated and expenditure on TT activities. The data on budget and expenditure is shown in Fig. 6. In case of a few universities, the expenditure exceeded the budget allocated. The anomaly could be due to the fact that a few universities received funds for research from government funding agencies, which was not considered as a part of intramural research budget. The researchers of the universities/institutes were aware of patenting, but the concept of commercializing the invention is not well entrenched in their minds. The initiatives of establishing an IP/TT cell among universities is yet to strategize regarding use of resources for technology commercialization. The primary focus of TT/IP cell in the organization was related to technology evaluation (49\%), licensing the invention (42\%), business

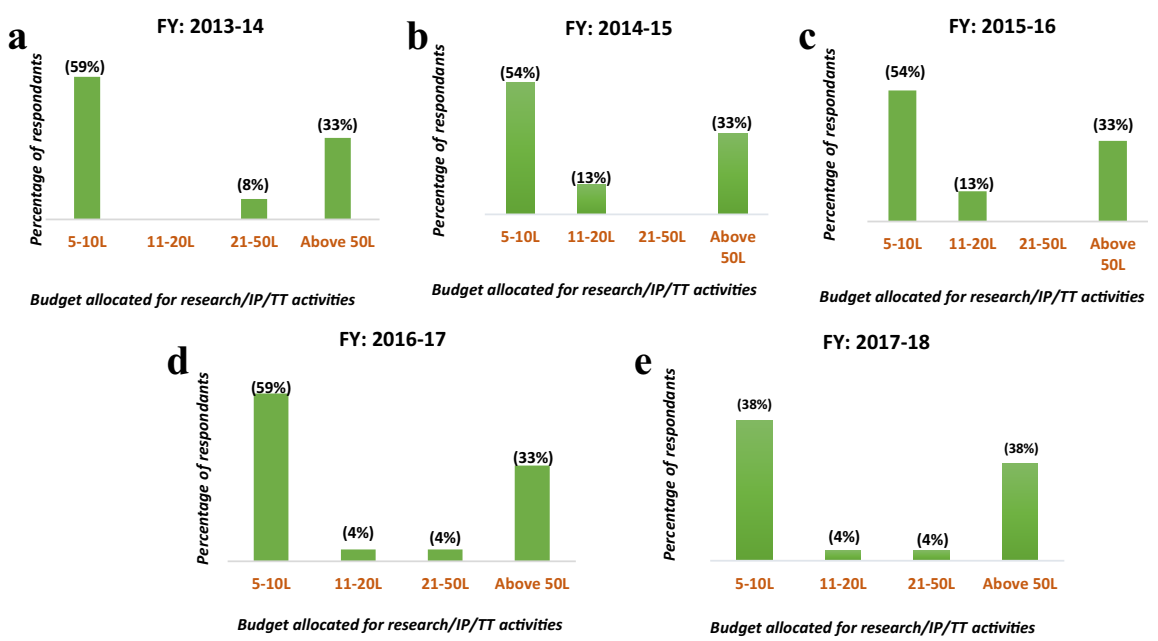

Fig. 5 Budget allocation for research /IP/TT activities in the past 5 years 


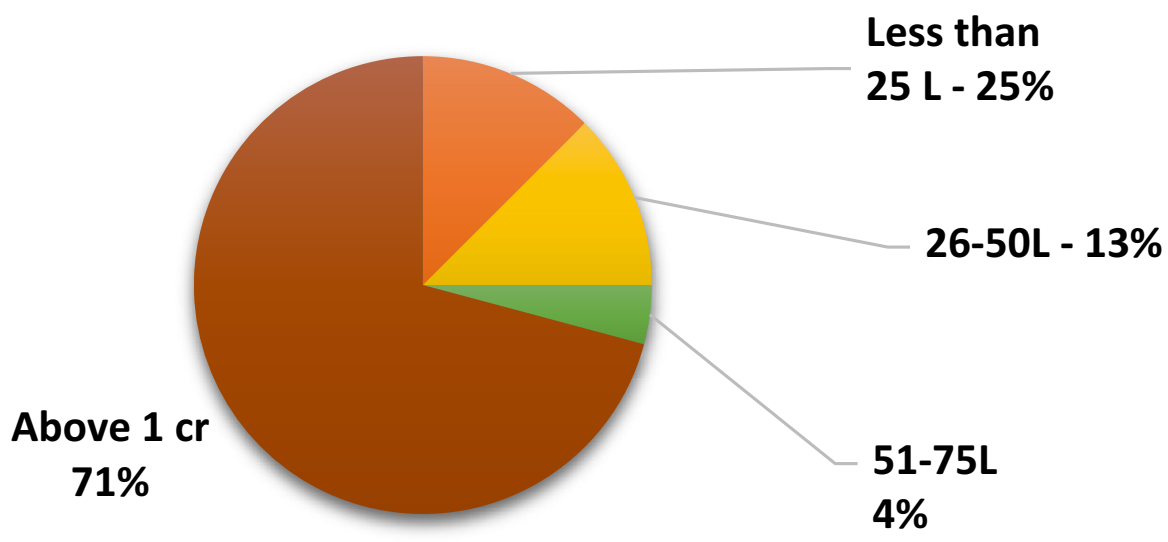

Fig. 6 Expenditure on university R\&D activities in past 5 years

management (6\%), and marketing (3\%). Most of the universities focus on all the above listed activities based on the requirements.

The number of active industrial collaboration was high (more than 30) among public universities. As shown in Fig. 7, the concept of technology commercialization is far behind among Indian universities compared with their counterparts in the developed countries.

As shown in Fig. 8, 13\% of the universities generated a revenue of more than INR 1 Crore through technology transfer activities, whereas other universities/ organization/institutes claim to have initiated discussion with industrial partners.

There is paucity of data and studies about university-industry technology transfer in Indian context. As a reference it would be interesting to compare it with other regions.

The Malaysian government under the 10th Malaysian Plan (2011-2015) had increased their R\&D budget to RM 741 million among the universities as a part of research grants. The 2011 report states that among the total number of 313

Fig. 7 Number of technologies transferred, licensed, sold in past 5 years

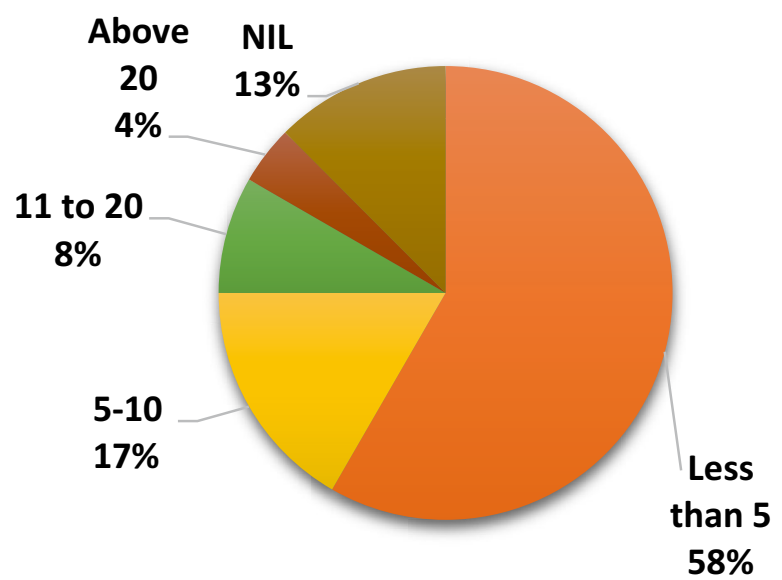


Fig. 8 Approximate revenue generated from transfer/sale from IP/TT in pipeline of IP/TT

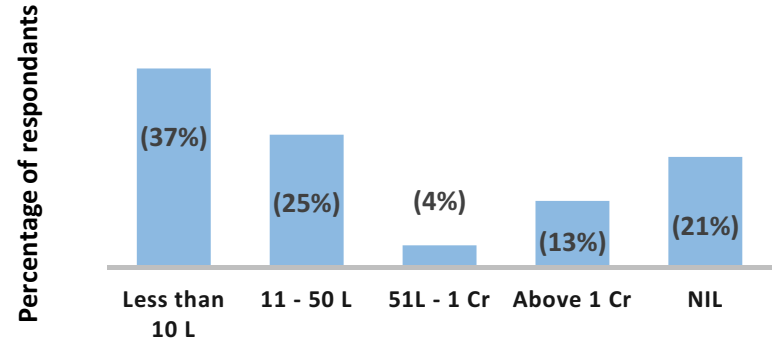

Approximate value of revenue generated from transfer/ sale of IP/TT in universities

inventions identified with potential of commercialization, only 58 research products were commercialized from 16 public funded universities. The critical factor identified as a barrier to commercialize R\&D results was lack of absorptive capacity and entrepreneurial skills among the researchers (Latif et al., 2016). According to a study on commercializing research findings at schools of agriculture in Iran, it was found that research activities carried out at universities are independent from the research priorities that are in demand. The study noted that the mechanism of delivering a technology are not adequately tested or have been ineffective (Mostoufi \& Highway, 2016).

The survey conducted in government research organizations in Sri Lanka reveals that there were 239 technological innovations, 11 new processes, and 11 new products, derived from the research organizations between the 2001 and 2008. Technology transfer was $80-90 \%$ successful, whereas technology commercialization rate was $40 \%$. The study concluded that the policies were not adequate to support technology commercialization and the attempts of transfer were a self-activated endeavor that lacked coordination (Perera et al., 2015). Further, the quantitative findings about universities with University Technology Transfer Office (UTTO) focus on commercializing technology, some strategies that were employed include: (a) agenda of research commercialization to be included in the mission statement, (b) allocated funding for internal research commercialization as a part of UTTO's budget, and (c) the funding for multi-purpose commercialization activities including prototype and business development. The qualitative study suggested the Australian UTTO is governed by panel of experts, with strong management support and most of all access to resources and staff with potential knowledge on commercialization (Alhomayden, 2017).

In the Republic of Serbia, research system is regulated under Law on Scientific and Research Activity and the innovation system is under Law of Innovation activity. As research organizations and institutes are not an integral part of innovation system, academia do not possess a strategic approach in research management creating innovation with a focus on commercialization (Belgrade, 2016). A survey conducted in three countries of Africa (Ghana, Kenya, and Zambia) suggested that dedicated Research and Development centers in Africa are limited and has shown a decline in past decades, as nearly $80 \%$ of budget allocated to top research centers goes toward salary for the staff. Moreover, the awareness of technology transfer at institutional 
level is negligible. Some of the research centers have expressed concerns on lack of multidisciplinary approach. It was recommended that relevant policies are framed and attempts made to recruit personnel trained in technology transfer (Africa U. N. E. C., 2013).

Our study focuses on three key aspects taking into account the challenges in university-industry technology transfer across regions: (1) the awareness and practice of patents and research commercialization among Indian academia, (2) comprehending strategies adapted to commercialize research activities, and (3) barriers in university-industry technology transfer. In terms of patents and technology transfer, Indian universities can be broadly classified into four categories: central government aided universities, state government funded universities, deemed to be universities, and state private universities/institutes. The most important findings are focused around the issues of patenting and technology transfer, not their strategic approach. The general outcome emerging from the study is discussed below.

Key aspect 1. The awareness and practice of patents and research commercialization among Indian academia

Compilation of the activities on patenting (inventions disclosed, patents filed and granted) and research commercialization was undertaken based on self- assessment. The word "declared" is associated with the realistic data provided by the university authorities which is emphasized in the study. The self-assessment of the analysis is shown in Table 2. Considering the number of patents filed in the past 5 years, there has been consistency in the filing pattern among the public funded universities/institutes, whereas there has been increased awareness in the pattern of filing among private and deemed to be universities. This could be due to the central government funds received by central and state universities. A general trend observed gives a positive correlation between financial support received by the public funded universities from the funding agencies such as Department of Science and Technology (DST) or Department of Biotechnology (DBT) and other government funding agencies under GOI. Similarly, active industrial collaboration among the government aided universities/institutes are relatively high compared with other universities/institutions. On the contrary, less than five technologies are transferred/licensed/sold by the public funded universities that corresponds to a large proportion (75-86\%) of public funded universities. The private organizations have higher number of active industrial collaborations yet minimal research commercialization activities. The revenue generated from the knowledge commercialization is comparatively high among the centrally funded universities with limited industrial partnership.

It is evident that with minimal industrial collaborations, high value is generated by the government universities/ institutes through knowledge transfer. Among private organizations despite high number of collaborations with the industrial partners, the value generated from the knowledge transfer is observed to be low. The results could lead to further studies exploring this inverse correlation.

Key aspect 2. Comprehending strategies adapted to commercialize research activities

Unlike in developed nations, there is no specific model proposed or practiced to commercialize research by Indian academia. As shown in Fig. 4, inventions in the field of medical and health sciences, biotechnology, and engineering derive 


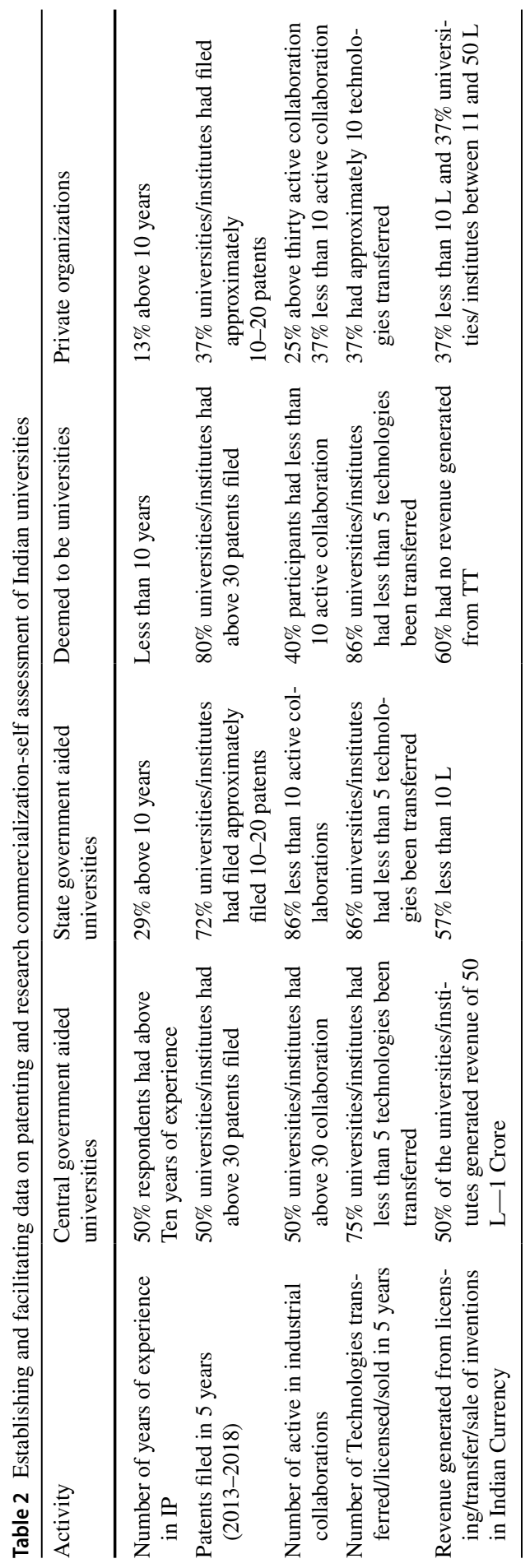


maximum potential for commercialization. The common strategy adopted to attract potential licensee is based on individual contacts of faculty with industry partners. The study emphasizes that the research undertaken in many universities/ institutes are far from meeting the industrial needs. The probable solutions could be to create centralized repositories of technologies available at universities on a platform maintained by Government of India to provide the required assistance, something similar to government e- Marketplace (GEM) (Vihar, 2019).

Key aspect 3. Barriers in university-industry technology transfer encountered by the faculty members are (1) lack of adequate resources and infrastructure; (2) lack of creativity and critical thinking in curricula; (3) over emphasis on publications due to lack of awareness on patenting, publishing, and commercializing the research; (4) IP cell or similar offices are established merely to meet statutory requirements; (5) lack of qualified people to manage IP/TT activities; and (6) conflict between commercially viable and academic research.

\section{Conclusion}

The survey results reveal that the practice of IP generation and technology transfer is underdeveloped in the country. In order to make technology transfer more relevant:

(1) Universities/institutes should leverage the expertise either in specific domains or pursue interdisciplinary research to attain high value through knowledge commercialization.

Universities should have people with the required skill sets manning the IP and tech transfer offices. Currently, in many universities, the responsibility is given to an individual who does not have required experience, expertise, and skills. This leads to a halo and the required outcomes expected by universities are not fulfilled. Additionally, the institutes should also promote interdisciplinary research to leverage domain strengths.

\section{(2) Focus on commercially viable research}

Universities should focus on outside-in approach where researchers are sensitized to work on commercially viable research. At present, in academia researchers follow an inside-out approach which leads to a knowledge gap. The inside-out approach is where researchers work on a problem that may address their inquisitiveness but does not lead to a research outcome that does not have commercial potential.

(3) identify mechanisms to reach out to and collaborate with industry through exhibitions, conference and research partnerships 
Universities/institutions should develop a mechanism wherein they showcase their research outcomes to industry with an intention to collaborate or license their invention. Current mechanisms to reach out to industry by academic institutions are inefficient and there exist no structure to strengthen industry-academia collaborations. These solutions though are not a guarantee to successful technology transfer but can help shape strategies to improve chances of stronger industry academia collaboration/technology commercialization among Indian universities.

Our current research has a few limitations. The data is collected from a small sample size. The respondent bias also cannot be ruled out while providing responses to the questionnaire.

In order to extract more meaningful data for analysis, it is required that a largescale study involving a larger sample size with varying size and structure of universities, geographical spread, management systems be carried out.

Funding Open access funding provided by Manipal Academy of Higher Education, Manipal

Open Access This article is licensed under a Creative Commons Attribution 4.0 International License, which permits use, sharing, adaptation, distribution and reproduction in any medium or format, as long as you give appropriate credit to the original author(s) and the source, provide a link to the Creative Commons licence, and indicate if changes were made. The images or other third party material in this article are included in the article's Creative Commons licence, unless indicated otherwise in a credit line to the material. If material is not included in the article's Creative Commons licence and your intended use is not permitted by statutory regulation or exceeds the permitted use, you will need to obtain permission directly from the copyright holder. To view a copy of this licence, visit http://creativecommons. org/licenses/by/4.0/.

\section{References}

Africa, U. N. E. C. for. (2013). National experiences in the transfer of publicly funded technologies in Africa: Ghana, Kenya and Zambia.

AICTE Training And Learning ( ATAL ) Academy. (2020). Government of India. 410917. https://www. aicte-india.org/sites/default/files/ATAL/atal\%20vision\%20mission.pdf

AICTE - India. (2019). Smart - India Hackaton. https://www.aicte-india.org/Initiatives/smart-india-hackathon

Alhomayden, R. S. R. (2017). University Technology Transfer Performance in Australia. Tez.

Baron, M. (2020). Open innovation capacity of the polish universities. Journal of the Knowledge Economy, (October 2015). https://doi.org/10.1007/s13132-017-0515-8

Belgrade. (2016). Research for innovation: strategy on scientific and technological development of The Republic of Serbia for the period 2016-2020. Ssrn. https://doi.org/10.2139/ssrn.2478304

Department of industrial policy and promotion, Ministry of Commerce \& Industry; Govt. of India. (2016). CIPAM: Cell for IPR Promotion and Management, 1-7. http://cipam.gov.in/wp-content/ uploads/2017/07/Scheme-IPR-Awareness.pdf

European commission. (2009). Expert GroupK nowledge Transfer. (2009), (November). http://www.descaagreement.eu/fileadmin/content/New_DESCA_Website/2009Expertgroup_on_knowledge_transfer_ final_report.pdf

Hyndman, K. G., Gruskin, S. M., \& Iyer, C. S. (2005). Technology transfer: what India can learn from the United States. Journal of Intellectual Property Rights, 10(September), 399-405.

Joseph, R. K. (2016). Who will Gain from the National IPRs policy, Research gate (July2016). http://www. desca-agreement.eu/fileadmin/content/New_DESCA_Website/2009Expertgroup_on_knowledge_ transfer_final_report.pdf 
Kumar, V., \& Jain, P. K. (2002). Commercializing new technologies in India: a perspective on policy initiatives. Technology in Society, 24(3), 285-298. https://doi.org/10.1016/S0160-791X(02)00009-X

Latif, N. S. A., Abdullah, A., \& Jan, N. M. (2016). A pilot study of entrepreneurial orientation towards commercialization of university research products. Procedia Economics and Finance, 37(16), 93-99. https://doi.org/10.1016/s2212-5671(16)30098-3

Livesey, F. (2014). Report on survey of Brazilian Technology Transfer Offices (TTOs), (June). https:// www.inova.unicamp.br/sites/default/files/images/FCO_BrazilTTOsurveyReport_0.pdf

MHRD's innovation council \& Govt. of India. (2019). Institution innovation council. https://www.mic. gov.in/iic.php\#

MHRD's innovation council, Ministry of Human Resource Development, AICTE. (2019). National innovation and startup policy 2019 for students and faculty. https://mic.gov.in/assets/doc/startup_ policy_2019.pdf

Mostoufi, A., \& Highway, A. (2016). Findings in Schools of Agriculture in Iran : a Qualitative, 5-14.

Nandagopal, M., Gala, K., \& Premnath, V. (2011). Improving technology commercialization at research institutes: Practical insights from NCL Innovations. Innovation Educators' Conference (IEC), Indian School of Business, Hyderabad, 1-12. https://www.venturecenter.co.in/pdfs/ISB-Conf-Paper-ver04.pdf

Pagar, S., Khivansara, A., Pagar, P., Gandhi, M., \& Jondhale, S. (2014). Review pilot study of entrepreneurial orientation towards commercialization of university research products . International Journal of Pure \& Applied Bioscience, 2(3), 145-153.

Perera, H., Mudalige, D., \& Liyanage, C. (2015). A case study of technology transfer process in a government research organization in Sri Lanka. Researchgate.Net, (March). Retrieved from. http://www.researchgate. net/profile/Darshana_Mudalige/publication/273629620_A_Case_Study_of_Technology_Transfer_ Process_in_a_Government_Research_Organization_in_Sri_Lanka/links/5506d3250cf2d60c0e6db0d1.pdf

Rath, S., Nathani, A., Patel, D., Kulkarni, P., \& Gota, V. (2014). Status of technology transfer in India-the much needed Magic Remedy. Current Science, 106(8), 1058-1060.

Srivastava, P., \& Chandra, S. (2012). Technology commercialization: Indian university perspective. Journal of Technology Management and Innovation, 7(4), 121-131. https://doi.org/10.4067/S0718-27242012000400010

Thompson, D. (2015). Tech transfer and commercialisation, (May). https://scienceportal.org.by/upload/ 2015/June/Inconet\%20EaP\%20-\%20Presentation/8\%20Thompson_Tech\%20Transfer\%20and\% 20Commercialisation.pdf

Vihar, J. (2019). guideline on government e- MARKETPLACE ( GeM ). https://www.suniv.ac.in/docs/ Guide-line-on-GeM-SU.pdf

Publisher's Note Springer Nature remains neutral with regard to jurisdictional claims in published maps and institutional affiliations.

\section{Authors and Affiliations}

\section{Ramya Ravi ${ }^{1}$ - Manthan D. Janodia² ${ }^{2}$}

Manthan D. Janodia

manthan.j@manipal.edu; manthan.janodia@gmail.com

1 Department of Pharmaceutical Quality Assurance, Manipal College of Pharmaceutical Sciences, Manipal Academy of Higher Education, Manipal, 576104, Karnataka, Manipal, India

2 Department of Pharmacy Management, Manipal College of Pharmaceutical Sciences, Manipal Academy of Higher Education, Manipal, 576104, Karnataka, Manipal, India 